\title{
PROBABILISTIC MODEL FOR FLEXURAL STRENGTH OF DENTAL COMPOSITES USED IN MODELING RELIABILITY OF THE "TOOTH-DENTAL COMPOSITE" SYSTEM
}

\author{
PROBABILISTYCZNY MODEL WYTRZYMAŁOŚCI NA ZGINANIE \\ KOMPOZYTÓW STOMATOLOGICZNYCH W ZASTOSOWANIU DO MODELOWANIA \\ NIEZAWODNOŚCI UKŁADÓW „ZĄB - KOMPOZYT STOMATOLOGICZNY"*
}

\begin{abstract}
In the article the application of Bayesian probabilistic modeling was presented as a way to standardize analytics of measurement results, which completes the operational and procedural standardization of determining the strength of dental composites. The traditional way of conducting studies of strength performed as services and calculations, and which do not refer to previous studies, was changed into an adaptation process of knowledge accumulation in a form of an increasing precise models. Probabilistic flexural strength models were used to create a reliability ranking of studied dental composites. Conceptualization of reliability of a biotechnological system, such as a "tooth-dental composite" required the expansion of the notion of "failure" with random events involving the occurrence of compatibility failure.
\end{abstract}

Keywords: probabilistic modeling, reliability of the "tooth-dental composite" system, dental composites, flexural strength.

\begin{abstract}
W pracy przedstawiono zastosowanie bayesowskiego modelowania probabilistycznego jako sposobu standaryzacji opracowania wyników pomiarów, uzupetniającego standaryzację operatorowo - proceduralna wyznaczania wytrzymałości kompozytów stomatologicznych. Tradycyjny sposób prowadzenia badań wytrzymatościowych, wykonywanych ustugowo i obliczeniowo nienawiazujacych do badań poprzednich, zmieniono $w$ adaptacyjny proces kumulacji wiedzy $w$ postaci coraz doktadniejszych modeli. Probabilistyczne modele wytrzymałości na zginanie wykorzystano do utworzenia rankingu niezawodnościowego badanych kompozytów stomatologicznych. Konceptualizacja niezawodności układów biotechnologicznych takich jak,,ząb-wypetnienie stomatologiczne" wymagała rozszerzenia zakresu pojęcia uszkodzenie o losowe zdarzenia polegające na zaistnieniu niezgodności pomiędzy komponentami układu biotechnologicznego (compability failure).
\end{abstract}

Stowa kluczowe: modelowanie probabilistyczne, niezawodność układów ząb-kompozyt stomatologiczny, kompozyty stomatologiczne, wytrzymałość na zginanie.

\section{Introduction}

Obtaining information and knowledge included in the production processes is a fundamental paradigm of production systems based on knowledge and information. It means that knowledge and information constitute one of the most important products - main or side - of each production process. The knowledge remains in the process as a wearfree production resource [3].

Flexural strength is one of the fundamental parameters characterizing dental composites. Flexural strength is measured using a 3-point flexural test (TFS) which is considered by the International Organization for Standardization as applicable in strength studies of polymer-based dental composites and described in standard PN-EN ISO 4049:2010E „Dentistry - Reconstructive polymer-based materials” introducing standard EN ISO 4049-2009 „Dentistry - Polymerbased restorative materials" [14] in Poland.

Flexural strength is a complex characteristic, sensitive to even insignificant structure heterogeneity and chemical composition, as well as the shape of the tested samples both at micro and macro scales. The result of the above includes scattered measurement results of samples made of the same material. In other words, the measurement result is burdened with uncertainty regarding the value of flexural strength. Probability is assumed as the measurement of uncertainty. It means that after a series of measurements the flexural strength of the studied material is known with the accuracy of the probability distribution. In literature $[10,15]$ it is assumed that the distribution is Weibull distribution, the cumulative distribution function of which is presented in formula 1:

$$
F\left(\sigma \mid m, \sigma_{0}, \sigma_{u}\right)=1-\exp \left[-\left(\frac{\sigma-\sigma_{u}}{\sigma_{0}}\right)^{m}\right]
$$

where:

$$
\begin{aligned}
& \sigma-\text { breaking stress, } \\
& \sigma_{0}-\text { scale parameter of Weibull distribution, } \\
& m-\text { shape parameter, } \\
& \sigma_{u}-\text { location parameter (in the considered case } \sigma_{u}=0 \text { ) }
\end{aligned}
$$

(*) Tekst artykułu w polskiej wersji językowej dostępny w elektronicznym wydaniu kwartalnika na stronie www.ein.org.pl 
$F\left(\sigma / m, \sigma_{o}, \sigma_{u}\right)$ - probability of destruction of the sample with breaking stress $\sigma$, for $\sigma \geq \sigma_{u}$.

Application of Weibull distribution as a flexural strength model for dental materials was considered in this article [10]. In order to estimate Weibull distribution parameters a method of double logarithmic grids was used [10]. It is a method based on classical mathematical statistics, in which distribution probability parameters are treated as fixed values for established conditions of the experiment, even though they are unknown. While the measurement results area random variable with values generated by probability distribution with specific, but unknown parameters. From an engineering point of view, it is the measurement resultsthat area stated fact, and therefore the uncertainty is related to the distribution parameters and not the measurement results. If we consider the distribution parameters to be random variables we deal with Bayesian statistics [5, 6]. Such an approach is meaningful in case of strength measurements in material engineering, anexample of which can be Bayesian Inference for NASA Probabilistic Risk and Reliability Analysis NASA/SP-2009-569, June 2009[2].

The purpose of this article is among others to present the application of Bayesian probabilistic modeling as the proposed method to determine and compare strength characteristics of dental materials. The authors believe that in order to increase the predictability and comparability of strength tests not only the method and measuring devices should be normalized, but also the method of developing measurement results and their formal interpretation. Application of Bayesian statistics has a significant advantage here over classical statistics because it is possible to combine knowledge with measurement results in a way which is compliant with engineering practices.

Another purpose of the article is to signal the problem of reliability of biotechnological systems. Conceptualization of reliability of biotechnological systems, such as the "tooth-dental filling" system requires the introduction of a new subcategory of failure ${ }^{1}$, which is compatibility failure. An event involving the occurrence of compatibility failure between a biological object and a dental component is treated as a new category of failure-like random events and to them we refer the notion of reliability of biotechnological systems. In accordance with standard PN-EN ISO 4049:2010 three types of non-compatibility should be considered: biological, aesthetical and compatibility related to strength. Each of these categories has more detailed sub-categories, specified in separate standards. In the above mentioned standard there are sub-categories of compatibility related to strength and anti-radiation.

\section{Bayesian probabilistic model for flexural strength of dental materials}

Bayesian probabilistic models (Bayesian networks) have graph representation $[8,11,12]$. Graph nodes represent values describing the modeled discipline in question. Each of these values has a determined set of values and measure of uncertainty regarding the values, set in the form of a priori probability distribution over the set of its values. Graph nodes are connected with arches representing a causal relationship.

Probability distributions related to child nodes of the other nodes are a priori conditional distributions. The Bayesian model should be structured in such a way so that the graph representing it does not contain cycles. Using the conditional independence principle a complete probabilistic characteristic is obtained in the form of factorised cumulative probability distribution [4].

Probabilistic models can be generative or discriminative. The essence of Bayesian statistics involves creation of generative models. A question regarding the total probability distribution of random variables is asked provided that their specific implementations are ob- served taking into account the knowledge of the cause and effect relationship between the variables. The hypothesis concern distribution parameters regarding which it is assumed that they are known with the accuracy of a priori probability distribution. Each inflow of new data (implementation of observed random variables) results in updating the conditional probability distributions of all variables in the model, including distribution parameters. Then a posteriori distributions of particular random variables are obtained, as well as total a posteriori probability distribution $[5,6,7,8,9]$.

Assuming that Weibull distribution is a probabilistic model for flexural strength of dental composites, the model in the form of Bayesian network is presented in Fig. 1. The graph has as many nodes as there are parameters in formula 1 (when building the network, the scale parameter was marked $\eta$ "eta", and the shape parameter - $\beta$ "beta")and nodes representing factors of the experiment. In this case they are: type of the material, type of light used in the hardening process and time of radiation.

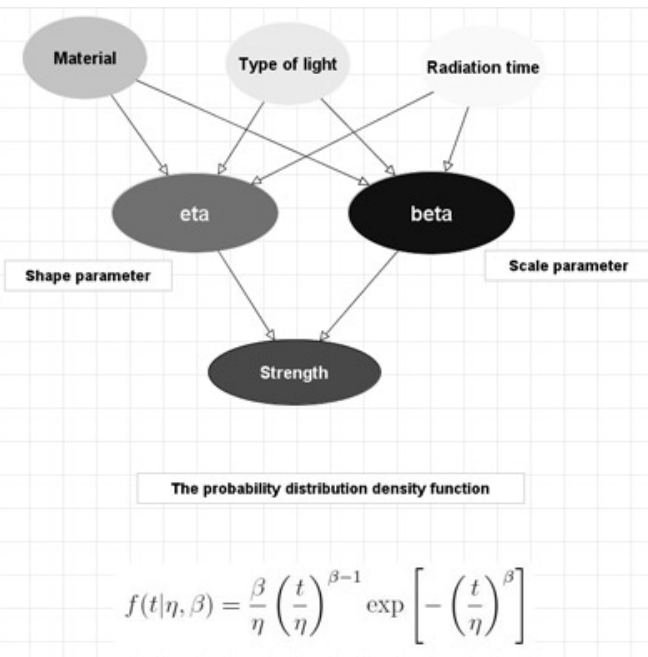

Fig. 1. Probabilistic model for flexural strength of dental materials

\section{3. "Learning the models" on examples of measurement results}

Results of measurements conducted and published in the article [11] were used. The data concerns dental composites based on siloranes and methacrylate compounds. They were: FiltekSiloran (FSi), Gradia Direct Anterior (GDA), Gradia Direct Posterior (GDP), Herculite XRV (H). Photopolymerization with two types of light: a diode lamp and a halogen lamp were applied. The assumed radiation time was $40 \mathrm{sec}$. and $60 \mathrm{sec}$. For flexural strength tests the three-point flexural strength test was used in accordance with the requirements of standard ISO 4049. Tested samples in an amount of $\mathrm{N}=20$ of each material had a form of cuboid beams $[1,4,10,13]$. Probabilistic modeling was conducted using the AgenaRisk ${ }^{2}$ program.

The purpose of learning the probabilistic network is to estimate parameters $\beta$ and $\eta$ for various materials and various conditions of the experiment. Learning the network involves backward propagation of results of the measurements of flexural strength (Fig. 2). At the initial stage of learning, the values of parameters $\beta$ and $\eta$ are uncertain, therefore the a priori probability distribution over the values of these parameters was assumed as steady in the range between 0 and 200 for parameter $\eta$ and between 1 and 20 for parameter $\beta$. Results of learning the network were presented in Fig. 3 and 4. 

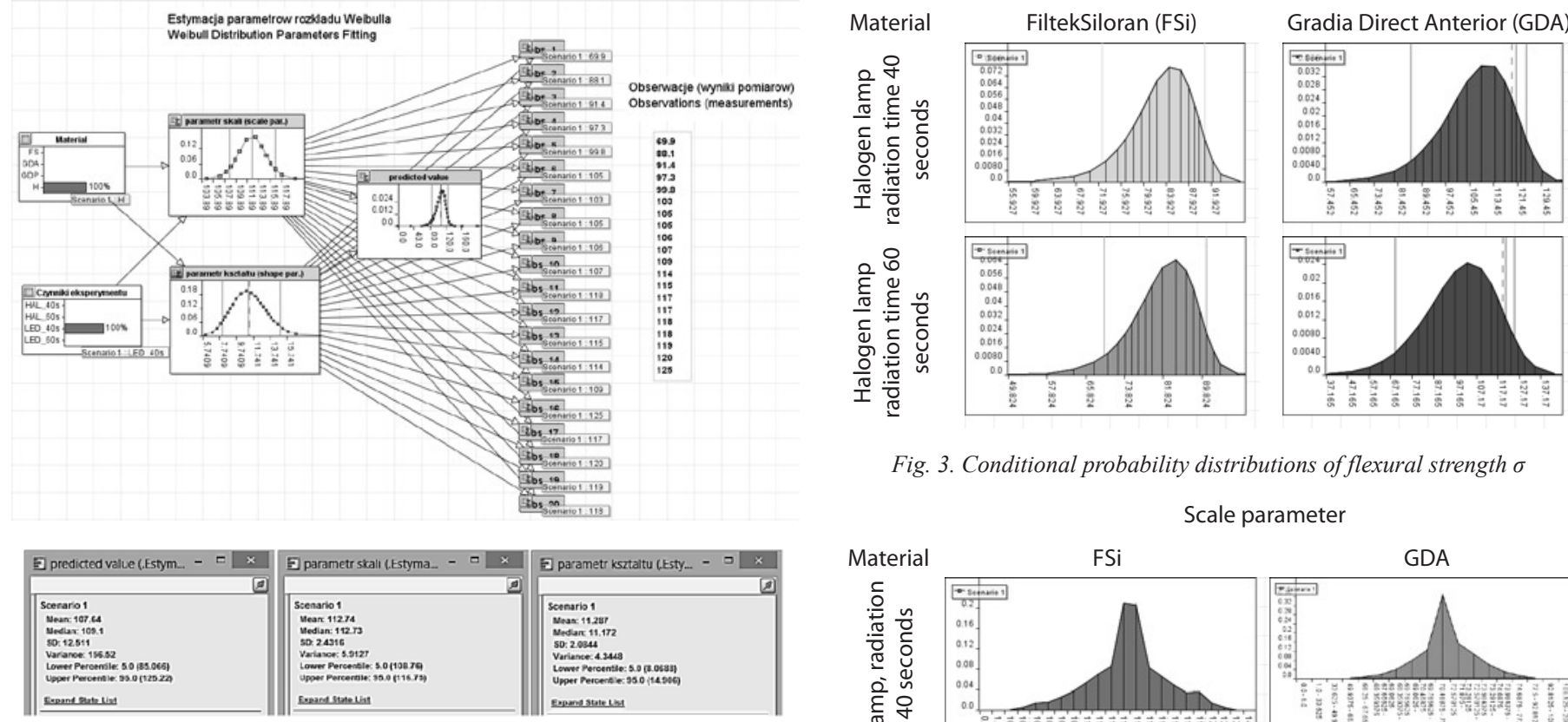

Fig. 3. Conditional probability distributions of flexural strength $\sigma$
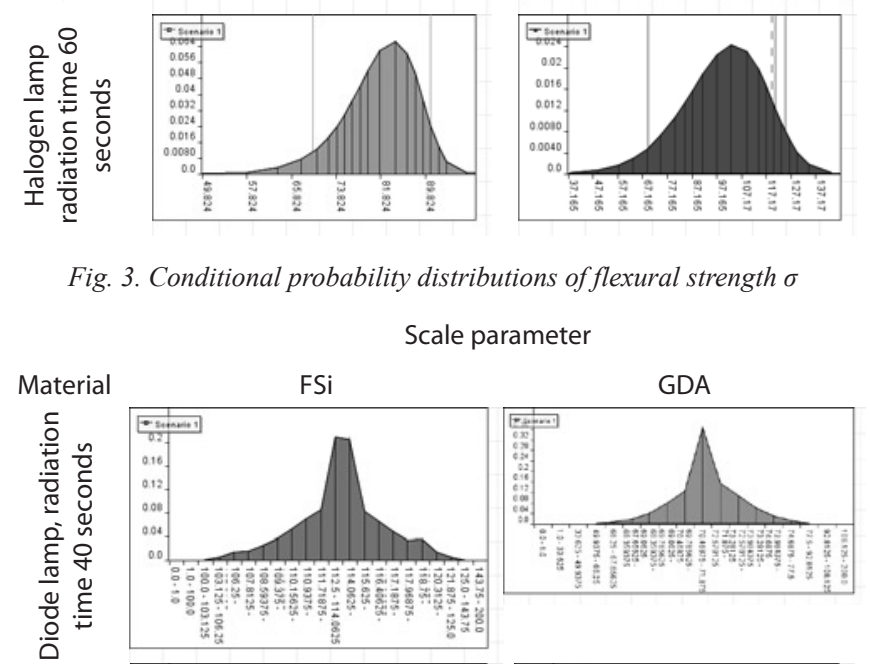

Fig. 2. Learning the network on the basis of measurement results
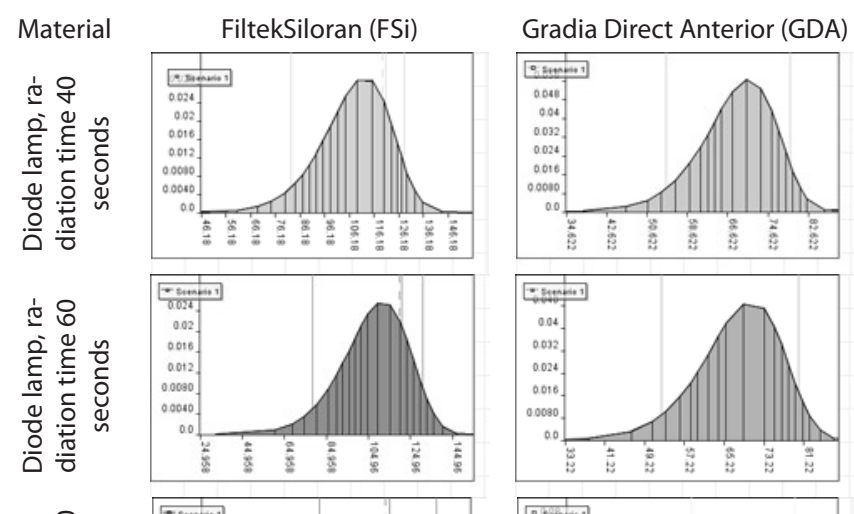

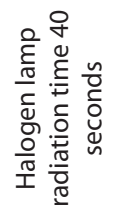
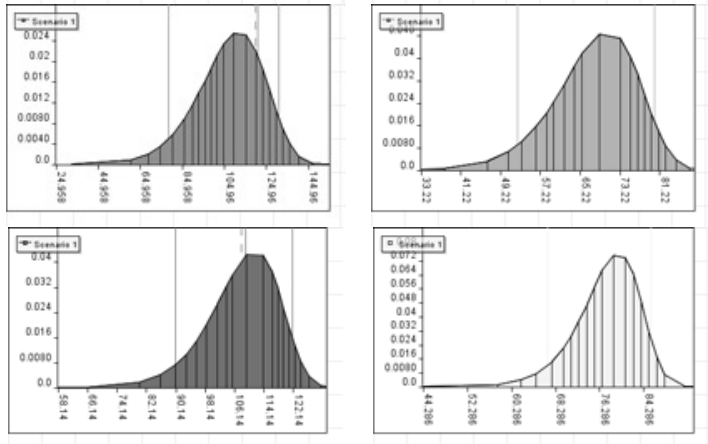

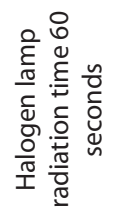
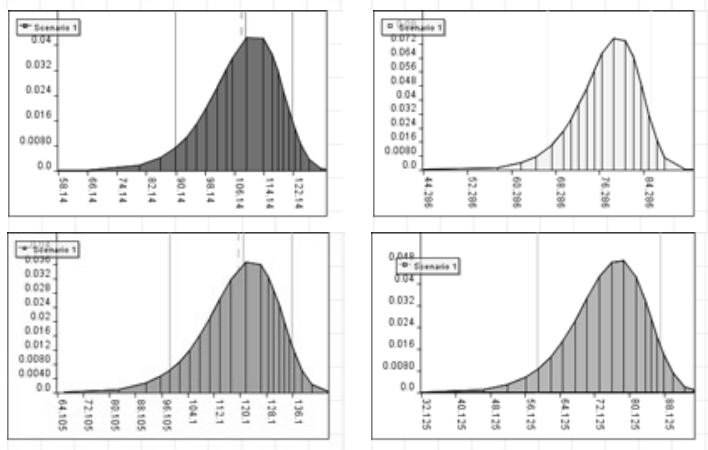

Material Gradia Direct Posterior (GDP)
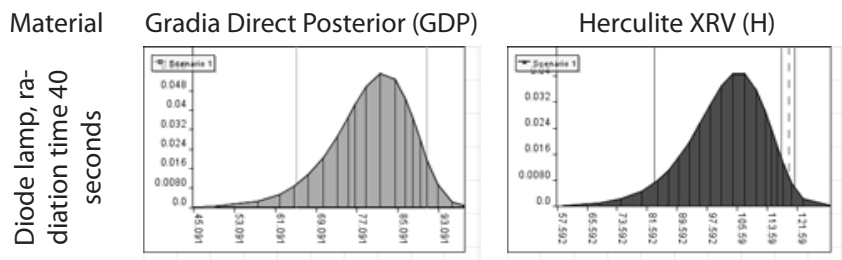

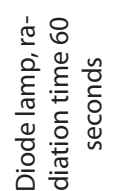
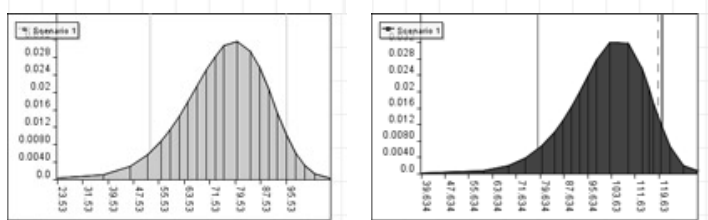

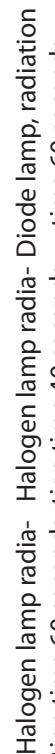
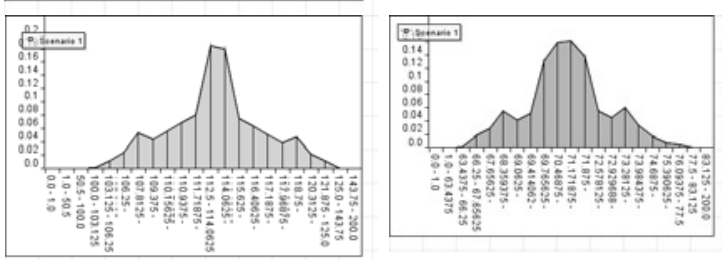

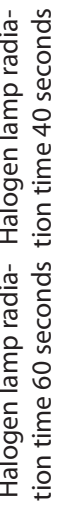
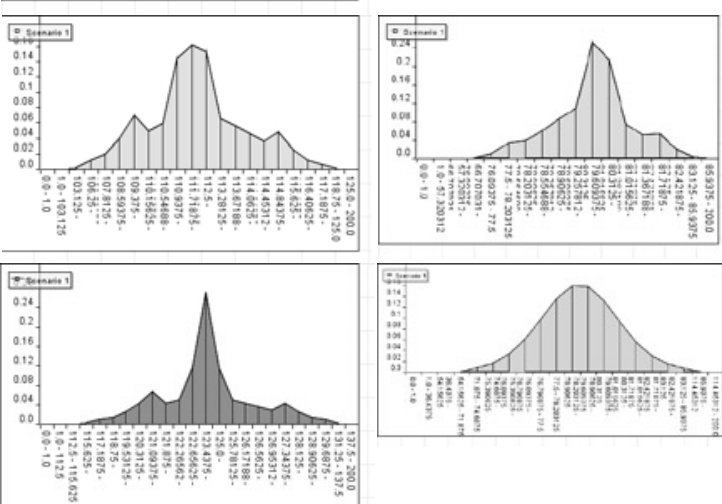

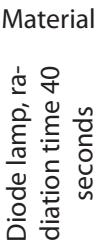
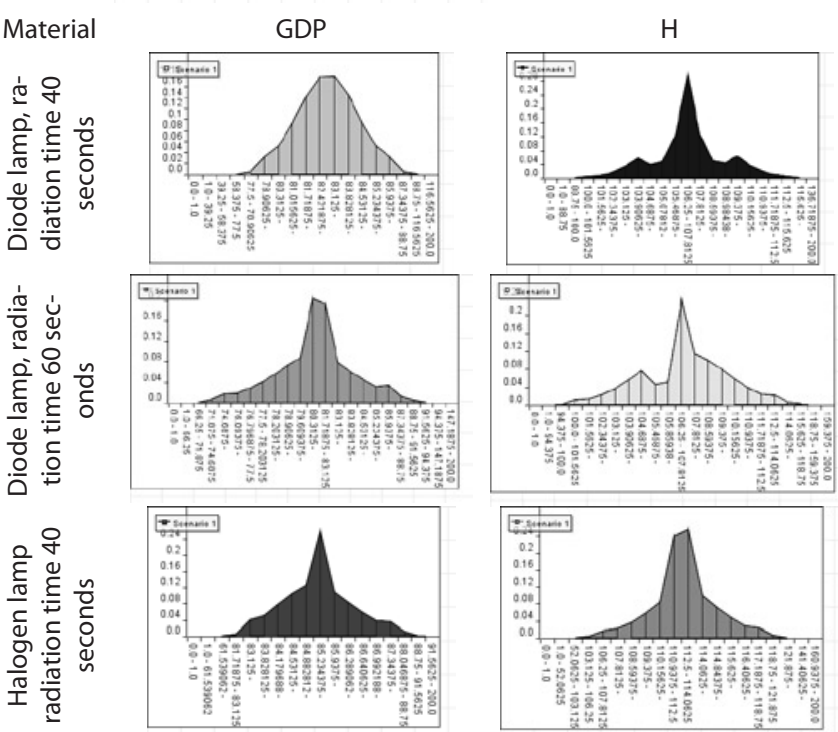
Scale parameter

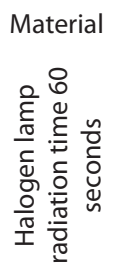
GDP
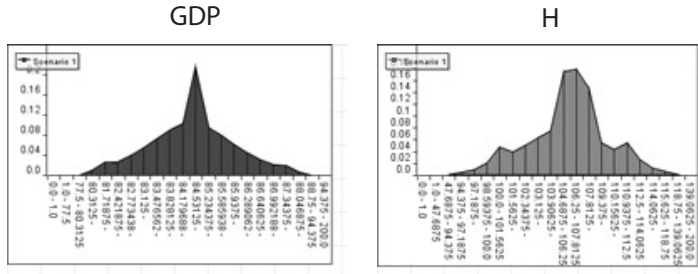

Shape parameter
Material

FS

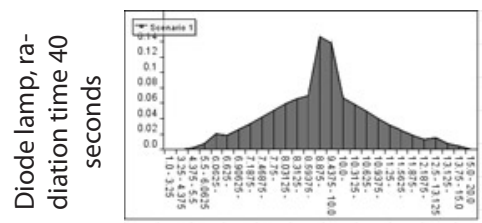

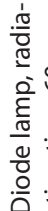
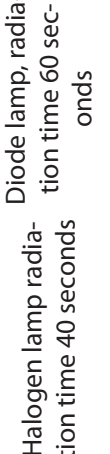

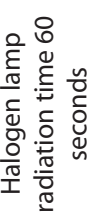

Material

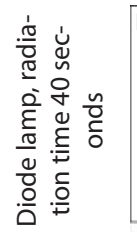

당ำ

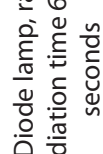
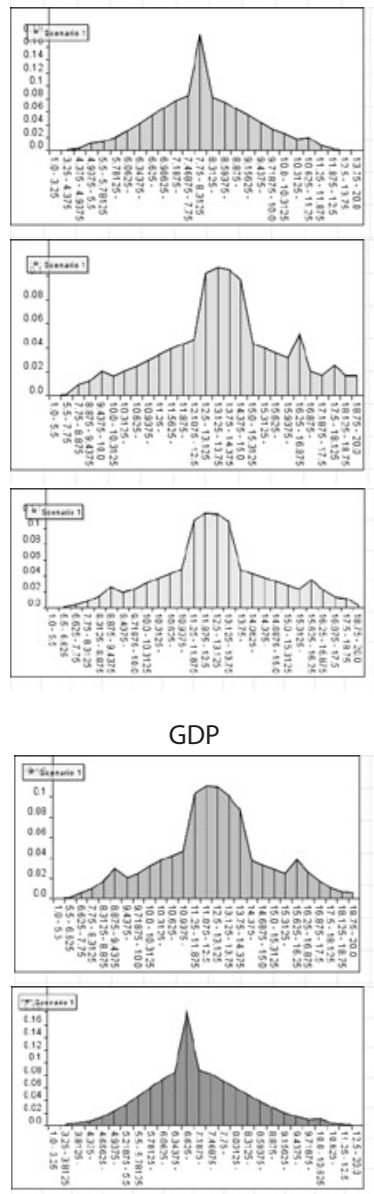

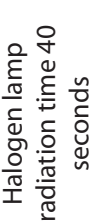

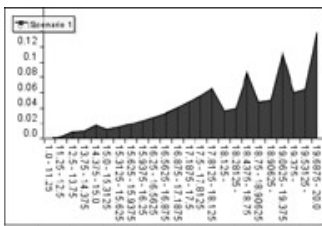

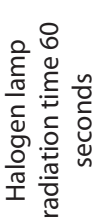

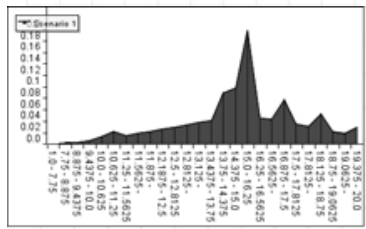

GDA
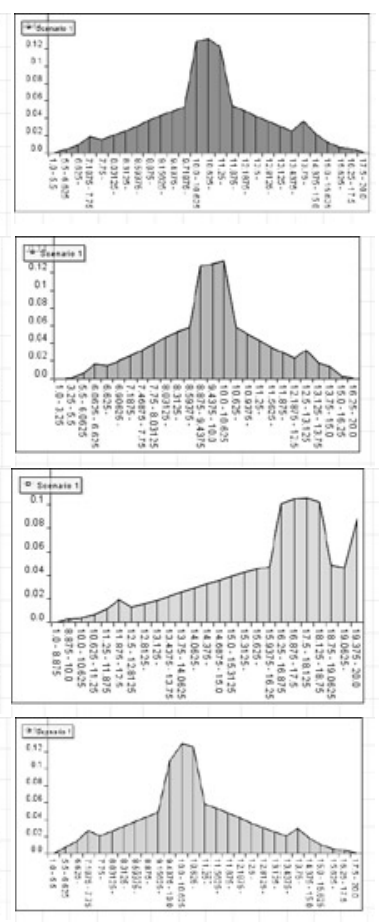

$\mathrm{H}$
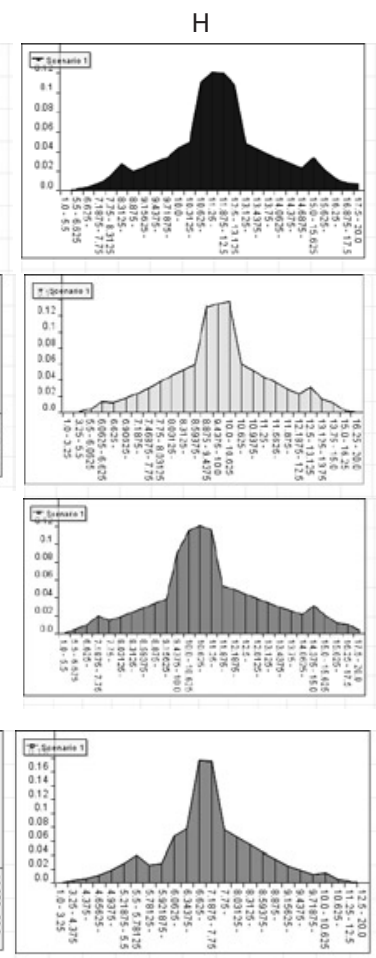

Fig. 4. A posteriori conditional probability distributions of Weibull distribution parameters

\section{Using the model to compare the studied materials regarding their flexural strength.}

The problem of comparing objects with properties known with the accuracy to probability distribution in classical statistics involves comparing average values, taking into account their confidence intervals. In the case of Bayesian statistics we have total probability distributions. It allows us to obtain answers with an accuracy up to probability distribution for numerous conclusive or comparative questions, e.g.:

- Isn't flexural strength of material A subject to radiation in accordance with procedure W1 lower than the flexural strength of the same material subject to radiation in accordance with procedure W2?

- Which of the studied materials with the same kind of treatment has the highest strength regarding the probability that the selected material will not be worse than other materials in further comparisons?

- Can the material which in the same conditions of treatment is worse than others be improved by the application of the same kind of treatment?

In Bayesian networks the comparison involves the activation of inferential procedures. The purpose of inference is in this case an answer to a question regarding the ratio (how many times?) or difference (by how much?) between the compared values with determined probability distributions. For this purpose to Bayesian network we add deterministic nodes representing the difference or the ratio of the compared values [3]. Exemplary results of the comparisons were presented in Figure 5.

Markings on Fig. 5:Material: FSI - FiltekSiloran, GDA - Gradia Direct Anterior, GDP - Gradia Direct Posterior, H - Herculite XRV.Radiation: HAL_40s - a halogen lamp, radiation time $40 \mathrm{sec}$., HAL_60s -a halogen lamp, radiation time $60 \mathrm{sec}$., LED_40s -a diode lamp, radiation time $40 \mathrm{sec}$. LED_60s - a diode lamp, radiation time $60 \mathrm{sec}$.

An example interpretation of comparisons included in figure 5 is as follows:

- in case of Fig. 5, a) flexural strength of the FSI material radiated with a halogen lamp for $40 \mathrm{sec}$. is compared with flexural strength of the FSI material radiated with a diode lamp for 40 sec. From the figure it can be concluded that the null hypothesis, stating that application of photopolymerization with a diode lamp results in lower flexural strength than photopolymerization with a halogen lamp, is real with a probability of 50,839\%. Such a result means that the difference of strength in these two cases is insignificant.

- in case of fig. 5, b) flexural strength of the GDA material is compared with the flexural strength of the GDP material both radiated using a halogen lamp for $40 \mathrm{sec}$. From the figure it can be concluded that the null hypothesis, stating that application of the GDP material results in lower flexural strength than GDS, is real with a probability of $25,067 \%$. Such a result means that the difference of strength in these two cases is significant for the benefit of the GDP material.

Other comparisons are interpreted analogically.

\section{Reliability model of the tooth-dental filling system}

To model this type of system Bayesian networks constitute a comfortable tool, and especially their sub-category - probabilistic Boolean networks. Nodes in these networks are in this case predicates representing particular types of non-compatibility of the biotechnological system (Fig. 6).

In the article we limited ourselves to consider reliability regarding strength compatibility failure. We treat an event involving the occurrence of strength incompatibility as a random event involving the 
a)

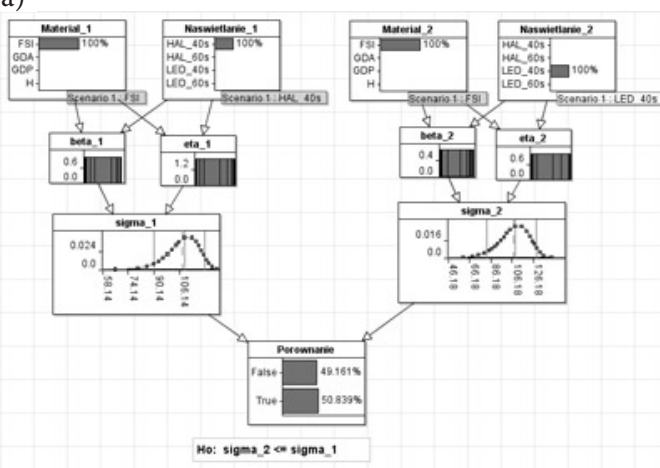

c)

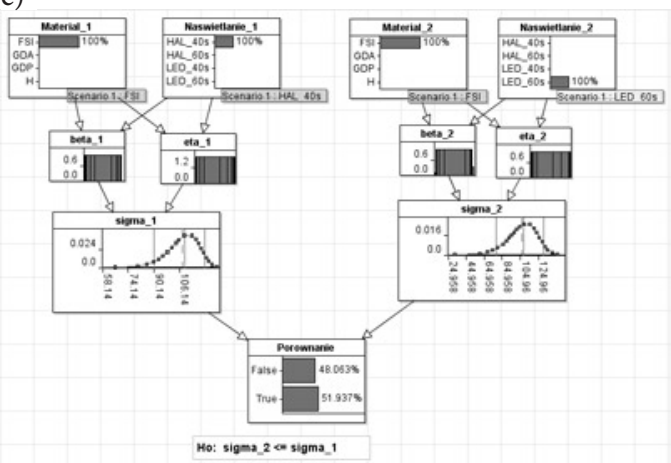

e)

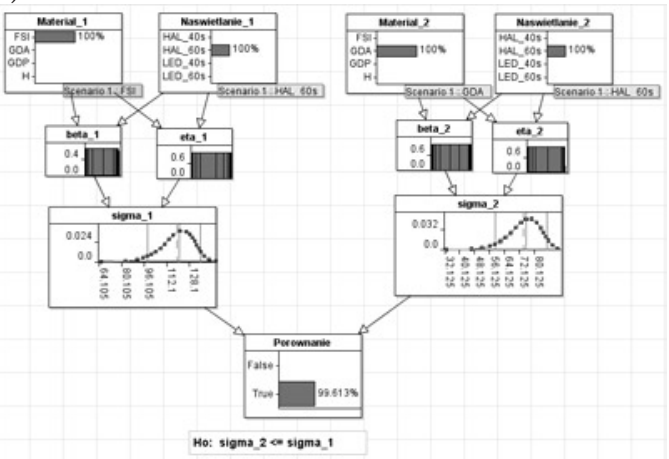

b)

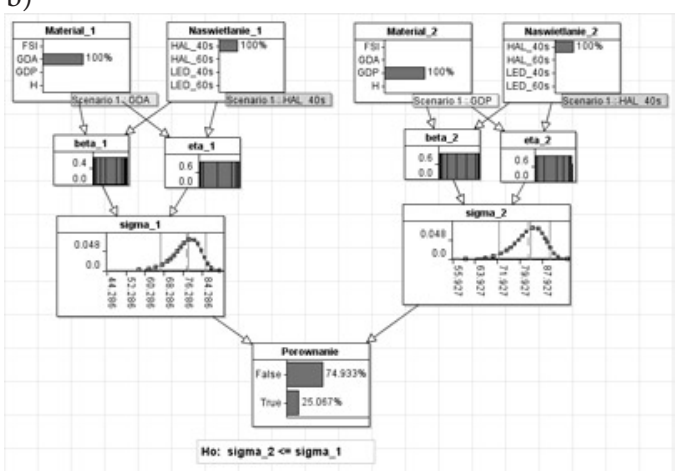

d)

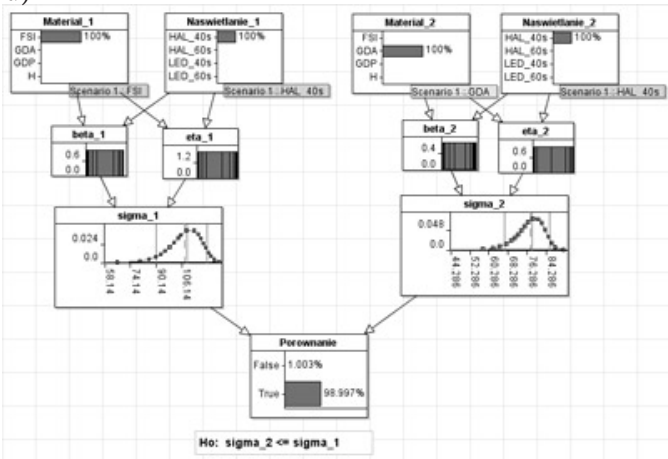

f)

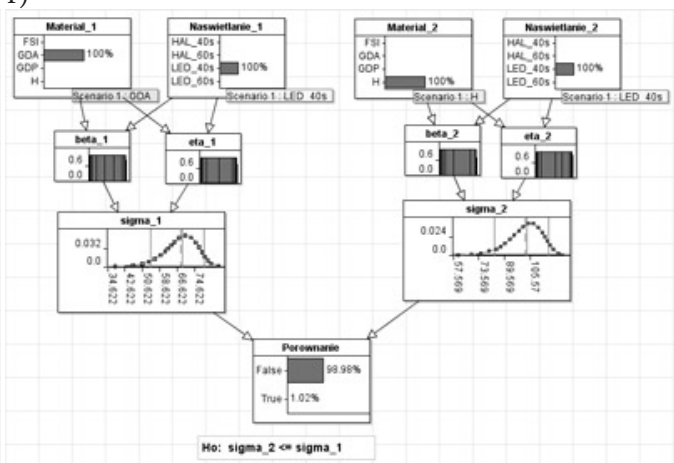

Flexural strength of the studied materials required by standard PN-EN ISO 4049:2010E (Type 1, class 2, group 1) is $80 \mathrm{MPa}$. Figure 7 presents a fragment of the network which allows compatibility failure for Filtek Siloran radiated with a diode lamp for 40 seconds to be determined. In this case the hypothesis stating that a material prepared in such as was is not compatible regarding strength is true; in other words its flexural strength is lower than $80 \mathrm{MPa}$.

Applying the measure of reliability of the "tooth-dental filling" system defined as probability of non-occurrence of compatibility failure for other dental materials and various conditions of their polymerization we obtained the results presented in Fig. 8. Most of the studied materials do not ensure strength compatibility within acceptable probability.

\section{Summary}

In the first part of the paper, an application of Bayesian probabilistic modeling was presented as a method to standardize analytics of measurement results, complementing the standardization determining strength of dental composites. The technology of Bayesian probabilistic modeling imposes a uniform and sufficiently expressive interpretation of obtained results. The product of this technology is a formal and executable model (knowledge representation sys-

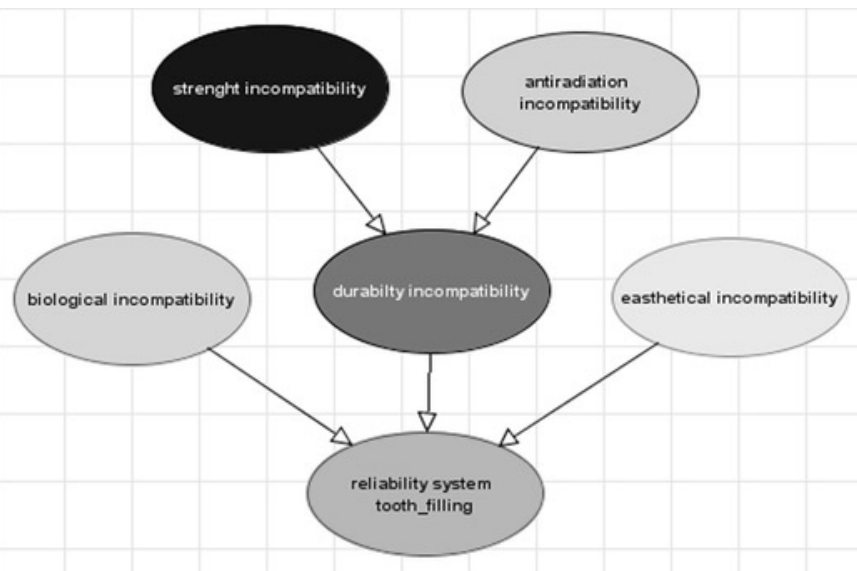

Fig. 6. Diagram of the network representing the reliability model of the toothdental filling system.

occurrence of a dental composite with lower flexural strength than required by the standard (at the moment of planting the dental material its strength is known with the accuracy up to the probability distribution). Probability of the occurrence of such an event constitutes the measure of failure (Fig. 7).
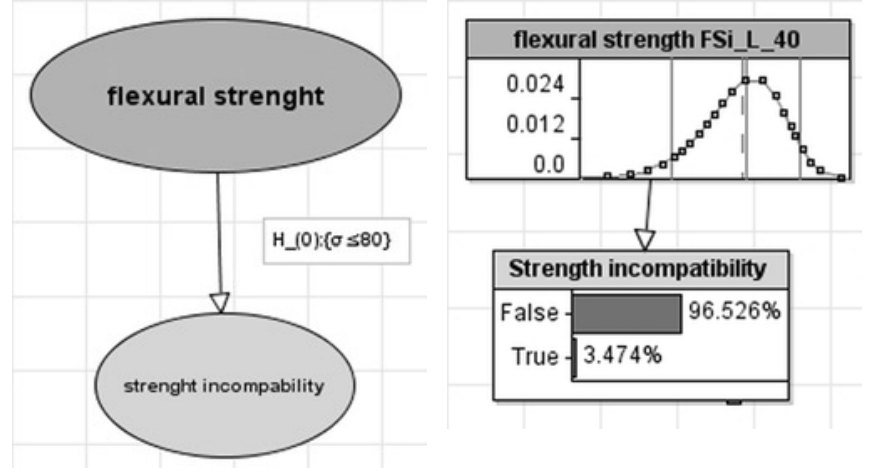

Fig. 7. Reliability of the "tooth-dental filling" system as probability of the occurrence of strength compatibility failure

tem). It is a change to the traditional manner of interpreting strength studies conducted upon request - studies which refer to previous studies regarding calculations, into an adaptation process of accumulating knowledge in the form of increasingly precise models.

In the second part of the article we proposed conceptualization and a method of reliability modeling of biotechnological systems re- 


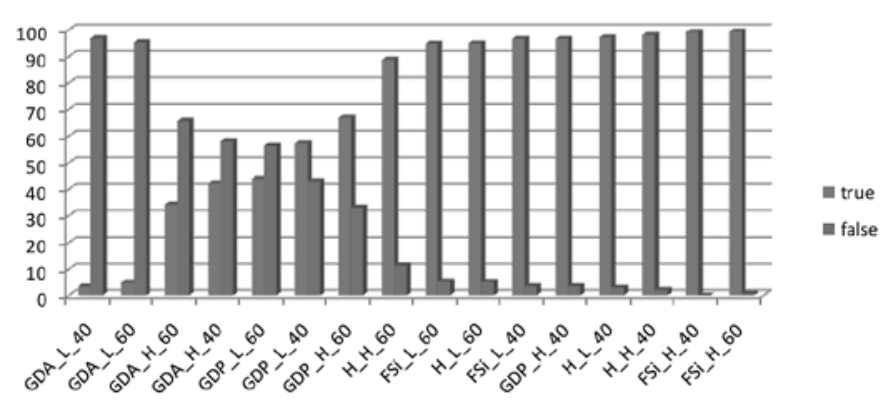

garding failures involving the occurrence of a specific type of compatibility failure between the components of the biotechnological system. In this case the appropriate method of reliability modeling involves Bayesian networks the nodes of which represent events of compatibility failure known with an accuracy up to probability distribution.

Fig.8. Ranking of dental materials regarding their strength compatibility

\section{References}

1. Asmussen E., Peutzfeldt A. Influence of UEDMA, BisGMA and TEGDMA on selected mechanical properties of experimental resin composites. Dental Materials, 1998 Jan;14(1): 51-6, http://dx.doi.org/10.1016/S0109-5641(98)00009-8.

2. Bayesian Inference for NASA Probabilistic Risk and Reliability Analysis NASA/SP-2009-569, June 2009.

3. Ben-Gal I., Bayesian Networks, in Ruggeri F., Faltin F. \& Kenett R., Encyclopedia of Statistics in Quality \& Reliability, Wiley \& Sons (2007).

4. Della Bona A. Characterizing ceramics and the interfacial adhesion to resin: I - The relationship of microstructure composition, properties and fractography. Journal Applied Oral Science 2005; 13: 1-9, http://dx.doi.org/10.1590/S1678-77572005000100002.

5. Fenton NE and Neil M. VisualisingRisk, www.agenarisk.com, 2006.

6. Fenton NE and Neil M. Combining Evidence in Risk Analysis Rising Bayesian Networks, Agena White Paper, Agena White Paper W0704/01, www.agena.co.uk, 2004.

7. Halpern J. Y. Reasoning about uncertainty. The MIT Press Cambridge, Massachusetts, London, 2005.

8. Jansen F. V. An introduction to Bayesian Networks. Taylor \& Francis, London 1996.

9. Neil M, Fenton NE, Nielsen L. Building large-scale Bayesian Networks. The Knowledge Engineering Review, 2000,(3)15: 257-284, http:// dx.doi.org/10.1017/S0269888900003039.

10. Niewczas A., Pieniak D., Ogrodnik P. Analiza niezawodnościowa wytrzymałości kompozytów stomatologicznych poddanych zróżnicowanym procedurom fotopolimeryzacji. Eksploatacja i Niezawodnosc - Maintenance and Reliability2012; 3(14): 249-255.

11. Pearl J. (1986). Fusion, Propagation, and Structuring in Belief Networks. Artificial Intelligence 29(3): 241-288, http://dx.doi.org/10.1016/00043702(86)90072-X.

12. Pearl J. Probabilistic reasoning in intelligent systems: networks of plausible reasoning. Morgan-Kaufman Publ. Inc. 1988.

13. Pieniak D., Niewczas A.M., Niewczas A., Bieniaś J. Analysis of Survival Probability and Reliability of the Tooth-composite Filling System. Eksploatacja i Niezawodnosc - Maintenance and Reliability 2011; 2(50): 25-34,

14. PN-EN ISO 4049:2010E.Stomatologia - Materiały polimerowe do odbudowy.

15. Rodriguez S. A. Jr., Ferracane J.L., Della Bona A. Flexural strength and Weibull analysis of a microhybrid and a nanofill composite evaluated by 3- and 4- point bending tests. Dent Mater 2008; 24(3): 426-431, http://dx.doi.org/10.1016/j.dental.2007.05.013.

\section{Grzegorz BARTNIK}

Department of Mechanical Engineering and Automation, University of Life Sciences Lublin, ul. Doświadczalna 50 A, 20-280 Lublin, Poland

\section{Daniel PIENIAK}

Department of Applied Mechanic, Main School of Fire Service, Warsaw ul. J. Słowackiego 52/54, 01-629 Warsaw , Poland

\section{Agata M. NIEWCZAS}

Department of Conservative Dentistry

Medical University of Lublin,

ul. Karmelicka 7, 20-081 Lublin, Poland

\section{Andrzej MARCINIAK}

University of Economics and innovation in Lublin ul.Projektowa 4, 20-209 Lublin, Poland

E-mail: agata.niewczas@umlub.pl,dpieniak@sgsp.edu.pl grzegorz.bartnik@up.lublin.pl, andrzej.marciniak@wsei.lublin.pl 